\title{
The Effectiveness of P53 Polymorphism in Susceptibility to Human Papillomavirus and Molluscum contagiosum Infections
}

\author{
Saba Amer Mughir* (D), Israa Adnan Ibraheam (iD) and Manar Mohammad Hasan \\ Al-Murshidi
}

Biology Department, College of Science for Women, Babylon University, Babylon, Iraq.

\begin{abstract}
P53 is Tumor suppressor gene which plays a main role in the genomic integrity preservation, mutation in this gene may change the susceptibility of individuals for several viral infections. This work designed to evaluate the effectiveness of P53 gene polymorphism (Arg/Pro) in susceptibility to infection with Molluscum contagiosum and Human Papillomavirus. Thirty one (31) invasive Molluscum contagiosum and $\mathbf{3 1}$ invasive Human Papillomavirus cases were studied and compared with $\mathbf{3 1}$ matched controls. Striking increase in (Arg/ Arg) and (Arg/Pro) and decrease of (Pro/ Pro) genotype frequencies have been observed in MCV and HPV infected patients, by comparing with controls, we didn't find significant relation between this infection and P53 genotypes. By investigate the frequency of mutation (Pro/Pro vs. Arg/ Arg and Arg/Pro) we found significant increasing of (Arg/Arg) and (Arg/Pro) in MCV infected patients $p=0.023<0.05$.we found that the carrying of $\mathrm{Arg}$ allele be more susceptible to infect with MCV and HPV while Pro/Pro genotype may confer protection against this viruses in our population.

Keywords: Tumor suppresser p53, Molluscum contagiosum, human papillomavirus, polymorphism, susceptibility.
\end{abstract}

\footnotetext{
*Correspondence: Sabaalammar2013@gmail.com
}

(Received: 17 April 2019; accepted: 28 May 2019)

Citation: Saba Amer Mughir, Israa Adnan Ibraheam and Manar Mohammad Hasan Al-Murshidi, The Effectiveness of P53 Polymorphism in Susceptibility to Human Papillomavirus and Molluscum contagiosum Infections, J Pure Appl Microbiol., 2019; 13(2): 1087-1093. doi: 10.22207/JPAM.13.2.47

(C) The Author(s) 2019. Open Access. This article is distributed under the terms of the Creative Commons Attribution 4.0 International License which permits unrestricted use, sharing, distribution, and reproduction in any medium, provided you give appropriate credit to the original author(s) and the source, provide a link to the Creative Commons license, and indicate if changes were made. 


\section{INTRODUCTION}

P53 are tumor suppressor proteins which play an important role in regulation of cell cycles, maintenance of genomic integrities, and encounter of environmental insults and cell apoptosis in addition to controlling the innate immunity of viral infection by regulate several sensors and receptors ${ }^{1}$. These proteins are encoded by P53 genes which located in human chromosome ${ }^{17}, \mathrm{a}$ common single nucleotide polymorphism (SNP) located in this gene in codon 72 is the changing of CCC coding for Proline to CGC coding for Arginine, this polymorphism found in $\mathrm{P} 53$ region rich with Proline ${ }^{2}$. The molecular studies expose that the variation in $72 \mathrm{C}$ allele cause the alternation in P53 gene transcription and modification of cell apoptotic potential ${ }^{3}$.

HPV human papillomavirus is circular, double strand DNA viruses with genome size 8 $\mathrm{Kb}$ have eight proteins-coding genes including L1, L2 gene (which coding for the capsid proteins or structural proteins) $E$ genes including $E^{1,2,4,5,6,7}$ coding for proteins which responsible for viral replication, transcription and transformation ${ }^{4}$. HPV belong to Papillomaviridea and over 130 different kind has been classified according to variation in L1 gene ${ }^{5}$ HPV transmitted directly through skin to skin contact either in children or through the sexual rote infect skin cells and cause benign or malignant wart or skin lesions ${ }^{6}$. The life cycle of HPV starting by entry of impaired skin barrier and infect the basal squamous cells and stimulate the epidermal cell proliferation, some of the viral proteins suppress some mechanisms that control the cell cycle, E6 protein bind to P53 protein, interfere with its function and stimulate its degradation?

Molluscum contagiosum virus (MCV) is a large, double stranded DNA virus, that infect epidermal cells (Keratinocytes) causing common skin tumor with distinctive intracytoplasmic inclusions $^{8}$. MCV belong to Poxviruses which known as common childhood disease that infect the skin in different part of body lead to produce dome-shaped and flesh-colored papules which are self-limiting ${ }^{9}$. Acanthosis and the big keratohyalin granules in addition to lack keratohylin granules reactivity to antifilaggrin monoclonal antibody suggesting that Molluscum contagiosum pathogenesis responsible for the abnormality of the epidermal cells differentiation ${ }^{8}$. The main functions of the skin are the Protection and defense against several stimuli and main function of the skin barrier is the protection from entry of microorganisms ${ }^{10}$. Skin composed of two structural compartments: the epidermis and the dermis which composed of several functionally different cells ${ }^{11}$. Stratum corneum cells (Keratinocytes) produce Filaggrin binding to Keratin fibers to form a protective tight barrier which prevents the entry of different pathogen $\mathrm{s}^{12}$, the impair of skin barrier cause several infection mostly caused by Herpis virus, Human Papillomavirus and Molluscum contagiosum virus ${ }^{13}$.

Since both Molluscum contagiosum and Human Papillomavirus infect the skin and cause the abnormality of the epidermal keratinocyte differentiation during both those viral infection, it was conceivable that the P53 gene activation or inactivation play a role in MCV and HPV pathogenesis.

Few studies in the Iraqi population have evaluated P53 gene polymorphisms and the susceptibility to HPV and MCV infections. Thus, we investigated the association of P53 R72P SNP with the risk of HPV and MCV infections.

\section{MATERIALS AND METHODS Subjects}

This prospective study involved selection of sixty two patients, thirty one patients infected with Molluscum contagiosum and other thirty one patients infected with Papillomavirus depending on the clinical diagnosis by Specialist Physician in Department of Dermatology / Margan teaching hospital/ Babylon Governorate between august 2018 to December 2018. The study involved blood collection. The blood samples were collected (about three $\mathrm{ml}$ for each patient) and inserted in EDTA tubes which refrigerated until DNA extraction.

This study included control group, thirty one people without any history of infection with both virus neither Molluscum contagiosum nor Papillomavirus, the blood samples from the control group were used.

\section{DNA extraction}

The DNA, of each patients and control group blood, was extracted by using $200 \mathrm{ml}$ from whole blood in addition to Favrogene human DNA 
extraction kit (Promega Co., USA) and following the instructions of manufacturer.

\section{DNA Genotyping}

The genotyping for P53 gene polymorphism was performed using the PCR technique (Polymerase Chain Reaction) and using Green master mix (promega), the genotyping of P53 R72P gene polymorphism accomplished by using the primer pair as previously used in study (Giannoudis et.al, 1999) ${ }^{14}$. Five microliter $(5 \mu \mathrm{l})$ of extracted DNA were used in 25 ML PCR containing $12.5 \mu \mathrm{l}$ green Master mix, $0.8 \mu \mathrm{l}$ of each forward and reverse primer (p53arg, Arg) (p53pro, Pro) and $5.9 \mu$ l nuclease free water. The PCR mixer use amplified by using this PCR program condition: first denaturation $94^{\circ} \mathrm{C}$ for $2 \mathrm{~min}$, and 35 cycle for $94^{\circ} \mathrm{C}$ for $45 \mathrm{sec}, 60^{\circ} \mathrm{C}$ for $45 \mathrm{Sec}, 72^{\circ} \mathrm{C}$ for $30 \mathrm{Sec}$, and the final step $72^{\circ} \mathrm{C}$ for $180 \mathrm{sec}$.

\section{Analyzing}

By using Gel electrophoresis the Reaction products has been analyzed using the $2 \%$ agarose gel containing red safe dye. Then the P53 gene polymorphism was determined by transilluminator.

\section{Statistical analyses}

The proportions of P53 gene polymorphism and the effectiveness of genotype variation were accomplished by comparing the genotype and allele frequencies of Molluscum contagiosum and Human Papillomavirus patients with the control (uninfected) group by using Chisquare analysis test ( $p<0.05$ consider significant) and odd-ratio (OD) test $\mathrm{CI} 95 \%$ using SPSS program IPM version 24.

\section{RESULTS}

The genotype of total subjects (31 patients infected with Molluscum contagiosum, 31 patients infected with Papillomavirus and 31 control uninfected group) were analyzed to investigate the association between p53 gene (Arg72Pro) polymorphism and susceptibility for infection with MCV and HPV. We observed an amplicon with size (141bp) in patients with Arginine homozygote (Arg/Arg) and (217bp) amplicon in patients with Proline homozygote (Pro/Pro) as seen in figure 1 and 2 respectively.

From analyzing we found the frequencies of genotypes as followed: for Molluscum patients (26\%) has (Arg/ $\mathrm{Arg}$ ) genotype, (71\%) with (Arg/ Pro) genotype and only (3\%) has (Pro/ Pro) genotype, while the results for Papillomavirus patients : $16 \%$ with (Arg/ Arg) genotype, 74\% with (Arg/Pro) genotype and $10 \%$ with (Pro/Pro)

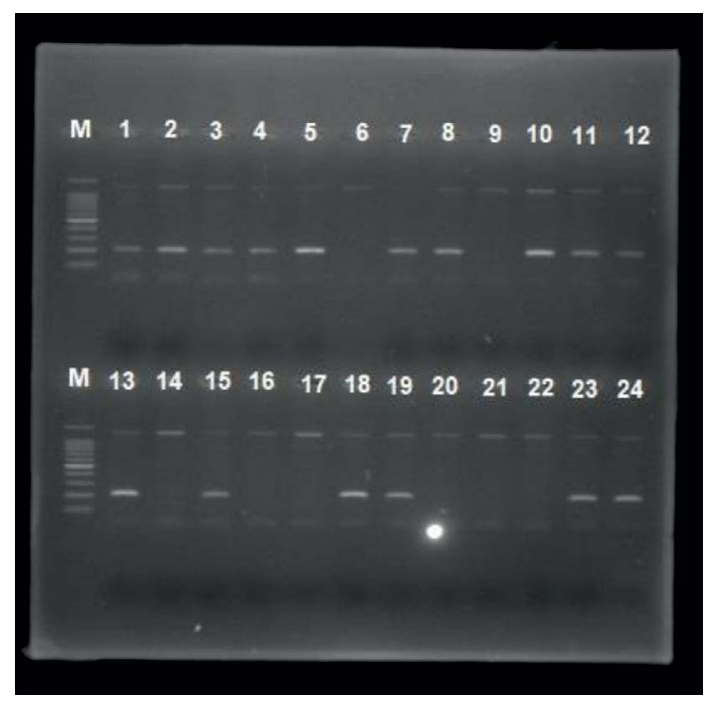

Fig. 2. Gel electrophoresis for PCR product of $P 53$ gene polymorphism (proline) M ladder, lane 1, 2, 3, 4, 5, 7, $8,13,15,18,19,23,24$ positive results lane $6,9,14,16$, $17,20,21,22$ negative results
Fig. 1. Gel electrophoresis for PCR product of P53 gene polymorphism (Arginine) M ladder, lane 1, 2, 3, 4, 6, 8 $9,12,13,15,16,17,18,20,21,22,23,25$ positive results lane $5,7,10,14,19,24$ negative results 
genotype. by carful analyzing of previous results we found that the genotype Arg/ Pro highly increase in patients more than other genotypes followed by the Arg/ Arg genotype while the Pro/Pro found in less frequencies than other genotypes.

When these results compared with the control group (35\% Arg/ Arg, 42\% Arg/ Pro and $23 \%$ Pro/ Pro), we didn't found significant association of allele frequencies between both MCV and HPV patients with the control group $\mathrm{p}=0.58, \mathrm{P}=0.718>0.05$ respectively (Arg72 allele vs. Pro72 allele $\mathrm{OD}=0.819, \mathrm{Cl}(0.4-1.67)$ as shown in table $1,2$.

By comparing all genotype of patients infected with MCV with the control group we found there is no significant association between genotypes and MCV infection (Arg/ Arg vs. Pro/

Table 1. Allele and genotype frequencies for P53 gene (Arg/ Pro) polymorphisms among Molluscum contagiosum positive patients and healthy (uninfected controls)

\begin{tabular}{|c|c|c|c|c|c|c|}
\hline \multirow[t]{2}{*}{ P53 } & \multicolumn{2}{|c|}{$\mathrm{MCV}$} & \multicolumn{2}{|c|}{ Control } & \multirow[t]{2}{*}{$P$ value } & \multirow[t]{2}{*}{ OD (CI95\%) } \\
\hline & no & $\overline{\%}$ & no & $\%$ & & \\
\hline \multicolumn{7}{|l|}{ Allele } \\
\hline Arg allele & 38 & $61 \%$ & 35 & $56 \%$ & 0.584 & Ref \\
\hline Pro allele & 24 & $39 \%$ & 27 & $44 \%$ & & $0.819(0.4-1.67)$ \\
\hline \multicolumn{7}{|l|}{ Genotype } \\
\hline $\mathrm{Arg} / \mathrm{Arg}$ & 8 & $26 \%$ & 11 & $35 \%$ & Ref & Ref \\
\hline Arg/Pro & 22 & $71 \%$ & 13 & $42 \%$ & 0.238 & $2.3(0.744-7.27)$ \\
\hline Pro/Pro & 1 & $3 \%$ & 7 & $23 \%$ & 0.29 & $0.19(0.02-1.92)$ \\
\hline
\end{tabular}

Arg; Arginine ,Pro; Proline, CI(95\%): 95\% the confidence interval, OR: Odds ratio, Ref: the references; * : statistically significant.

Table 2. Allele and genotype frequencies for $P 53$ gene (Arg/Pro) polymorphisms amongst Papillomavirus infected patients and healthy group (uninfected controls)

\begin{tabular}{llllll}
\hline P53 & HPV & & Control & P value & OD (Cl95\%) \\
\cline { 2 - 3 } & no $\%$ & & \\
\hline
\end{tabular}

\begin{tabular}{|c|c|c|c|c|c|c|}
\hline \multicolumn{7}{|l|}{ Allele } \\
\hline Arg allele & 33 & $53 \%$ & 35 & $56 \%$ & 0.718 & Ref \\
\hline Pro allele & 29 & $47 \%$ & 27 & $44 \%$ & & $0.878(0.433-1.781)$ \\
\hline \multicolumn{7}{|l|}{ Genotype } \\
\hline Arg/Arg & 5 & $16 \%$ & 11 & $35 \%$ & Ref & Ref \\
\hline Arg/Pro & 23 & $74 \%$ & 13 & $42 \%$ & 0.06 & $3.89(1.107-13.68)$ \\
\hline Pro/Pro & 3 & $10 \%$ & 7 & $23 \%$ & 1 & $0.943(0.169-5.248)$ \\
\hline
\end{tabular}

Arg; Arginine, Pro; Proline, CI(95\%): 95\% the confidence interval, OR: Odds ratio, Ref: the references; * : statistically significant.

Table 3. Mutation frequencies of $P 53$ (Arg/Pro) polymorphisms among Molluscum contagiosum positive patients and healthy (uninfected controls)

\begin{tabular}{|c|c|c|c|c|c|c|}
\hline \multirow[t]{2}{*}{ P53 mutation } & \multicolumn{2}{|c|}{$\mathrm{MCV}$} & \multicolumn{2}{|c|}{ Control } & \multirow[t]{2}{*}{$P$ value } & \multirow[t]{2}{*}{ OD (Cl95\%) } \\
\hline & no & $\%$ & no & $\%$ & & \\
\hline $\begin{array}{l}\text { P53 mutation } \\
\text { (Arg /Arg, } \\
\text { Arg / Pro) }\end{array}$ & 30 & $97 \%$ & 24 & $77 \%$ & $0.023^{*}$ & $4.444(0.7-28.23)$ \\
\hline Pro/ Pro & 1 & $3 \%$ & 7 & $23 \%$ & & Ref \\
\hline
\end{tabular}

Arg; Arginine, Pro; Proline, CI(95\%): 95\% confidence interval, OR: Odds ratio, Ref: the references; *: statistically significant. 
Table 4. Mutation frequencies of $P 53$ (Arg/Pro) polymorphisms amongst Papillomavirus infected patients and healthy group (controls)

\begin{tabular}{lccccccc}
\hline P53 mutation & \multicolumn{2}{c}{ HPV } & & \multicolumn{2}{c}{ Control } & P value & OD (CI95\%) \\
\cline { 2 - 5 } \cline { 5 - 7 } & no & $\%$ & & no & $\%$ & & \\
\hline $\begin{array}{l}\text { P53 mutation } \\
\text { (Arg /Arg, }\end{array}$ & 28 & $90 \%$ & 24 & $77 \%$ & 0.16 & $1.795(0.674-4.781)$ \\
Arg / Pro) & & & & & & Ref \\
Pro/ Pro & 3 & $10 \%$ & 7 & $23 \%$ & & \\
\hline
\end{tabular}

Arg; Arginine, Pro; Proline, Cl(95\%): 95\% confidence interval, OR: Odds ratio, Ref: the reference Allele.

Pro: $P=0.29, \mathrm{OD}=0.19,95 \% \mathrm{Cl}:(0.02-1.92), \mathrm{Arg} / \mathrm{Arg}$ vs. Arg/Pro: $P=0.238 \mathrm{OD}=2.3,95 \% \mathrm{Cl}(0.744-7.27))$. Also there is no significant association between genotypes frequencies of HPV infected group and control group (Arg/ Arg vs. Pro/ Pro: $P=1, \mathrm{OD}=$ 0.943, 95\% Cl:(0.169-5.248), Arg/Arg vs. Arg/Pro: $\mathrm{P}=0.06 \mathrm{OD}=3.89,95 \% \mathrm{Cl}(1.107-13.68))$ Table 1 and Table 2.

Also we investigate the mutation frequency in P53 gene (Arg 72 Pro) polymorphism and their association with increase susceptibility to infection with both viruses, for MCV patients compared with the control group: (Pro/Pro) vs. $($ Arg $/$ Arg $)+($ Arg $/$ Pro $): P=0.023<0.05, \mathrm{OR}=$ 4.444, $\mathrm{Cl}(95 \%)$ : (0.7-28.23) the mutant type are significantly increase for MCV patients table 3 , for HPV patients compared with control group : (Pro/ Pro) vs. $($ Arg/Arg) $+($ Arg/Pro $): P=0.16>0.05, O R$ $=1.795, \mathrm{Cl}(95 \%):(0.674-4.781)$ the mutation frequency has no significant association with susceptibility to infection with HPV table ${ }^{4}$.

\section{DISCUSSION}

Since the P53 gene polymorphism has been identified, several studies investigate the effectiveness of P53 gene polymorphism on susceptibility to several diseases. The evidence of the effectiveness of P53 gene Arg72Pro single nucleotide polymorphism for the risk of HPV infection is inconsistent, in addition, there is no previous study devoted to detect the association between P53 gene polymorphism (Arg72Pro) (SNP) with susceptibility to infection with Molluscum contagiosum and Human Papillo-mavirus. This prompted us produce this study to discover the association between this SNP and susceptibility to MCV and HPV infections.
In the current study, we found that the patients who carrying the ( $\mathrm{Arg} / \mathrm{Arg}$ ) genotype and (Arg/Pro) genotype have the high percentage that the patients who carrying the (Pro/Pro) genotype. P53 gene polymorphism may be influenced by the different ethnic group ${ }^{14}$.

During Molluscum contagiosum infection, MCV release growth factor - like polypeptide which regulate cell proliferation ${ }^{15}$. Other study found that the MCV genome coding for intracellular defense molecule which provide protection against the toxic effect from peroxide release through the phagocytic leukocytes and prevent apoptosis of the infected cells ${ }^{16}$. HPV release proteins that interfere with the P53 gene (tumor suppresser gene) and targeting for degradation which is lead for loss of P53 mediate apoptosis ${ }^{17}$. Which that demonstrate the abnormality of keratinocyte differentiation during both those viral infections.

Previous study suggested that the P53 protein containing Arginine are more susceptible to elimination by HPV proteins ${ }^{18}$. Therefore its increase HPV infection susceptibility, which that explain our results that the majority of patients with MCV and HPV infection were carrying the mutant allele ( $\mathrm{Arg} / \mathrm{Arg}$ or $\mathrm{Arg} / \mathrm{Pro}$ ), suggesting that the mutant type increase significantly the susceptibility to MCV infection and although we didn't found significant association with HPV infection but still the patients carrying of mutant allele $(90 \%)$ more than the normal one $(10 \%)$, suggesting increase the susceptibility to HPV infection.

Several studies examined the relation between $\mathrm{p} 53$ gene polymorphism and the susceptibility to disease but the results of these studies are Contradictory, P53 polymorphism 
associated with the HPV infection and development of head and neck cancers ${ }^{3}$, development of oral cancer ${ }^{14}$ and cervical cancer ${ }^{19}$, In contrast, some studies found the opposite result where the P53 gene poly-morphism are not associated with HPV infections ans lesion progressions ${ }^{1}$ and development of skin cancer ${ }^{20}$.

\section{CONCLUSION}

For first time, this result designed to detect the relationship between P53 gene polymorphisms and susceptibility to infection with Molluscum contagiosum and Human Papillomavirus. Our results suggesting that p53 (Arg/Pro) gene polymorphism contribute to MCV and HPV pathogenesis, the mutant type ( $\mathrm{Arg} / \mathrm{Arg}$, $\mathrm{Arg} / \mathrm{Pro}$ genotypes) contribute to increase the susceptibility for MCV and HPV infections while the Pro/Pro genotype may confer protection against such viruses in our population.

\section{ACKNOWLEDGEMENTS}

Special thanks for doctors and staff, at Dermatology unit in Marjan Teaching Hospital, whom helped us to accomplish this work.

\section{CONFLICTS OF INTEREST}

The authors declares that there is no conflict of interest.

\section{AUTHORS' CONTRIBUTIONS}

All authors listed have made a substantial, direct and intellectual contribution to the work, and approved it for publication.

\section{FUNDING}

None.

\section{DATA AVAILABILITY}

All datasets generated or analyzed during this study are included in the manuscript.

\section{ETHICS STATEMENT}

This article does not contain any studies with human participants or animals performed by any of the authors.

\section{REFERENCES}

1. Lahsen A.O., Baba H., Bensghir R., Fayssel N., Sodqi M., Marih L., Nadifi S., Wakrim L., El-Filali K. M., Ezzikouri
S. TP53 R72P Polymorphism and Susceptibility to Human Papillomavirus Infection Among Women With Human Immunodeficiency Virus in Morocco:A Casecontrol Study. J. Cancer Prev., 2017; 22: 248-253, doi. org/10.15430/JCP.2017.22.4.248.

2. Matlashewski G.J., Tuck S., Pim D., Lamb P., Schneider J., Crawford L.V. Primary structure polymorphism at amino acid residue 72 of human p53. Mol. Cell Biol., 1987; 7: 961-3.

3. Al-Hadyan K.S., Al-Harbi N.M., Al-Qahtani S.S. \& Alsbeih G.A. Involvement of Single-Nucleotide Polymorphisms in Predisposition to Head and Neck Cancer in Saudi Arabia. Genetic Testing and Molecular Biomarkers, 2012; 16(2): 95-101.doi: 10.1089/gtmb.2011.0126.

4. Brianti P., Flammineis E.D., Mercuri S. R. Review of HPVrelated diseases and cancers. New Microbiologica, 2017; 40(2): 80-85

5. Stanley M. Pathology and epidemiology of HPV infection in females. Gynecologic Oncology, 2010; 117(2): S5-S10.doi:10.1016/j.ygyno.2010.01. 024.

6. Tulay P., Serakinci N. The role of human papillomaviruses in cancer progression. J. Cancer Metasta Treat, 2016; 2: 201-13.

7. Patrick Bacaj M.D., David Burch M.D. Human Papillomavirus Infection of the Skin. Arch. Pathol. Lab. Med., 2018; 142: 700-705; doi: 10.5858/arpa.20170572-RA.

8. Simonart T., Fayt I., \& Noel J. An immuno-histochemical study of abnormal keratinocyte proliferation in molluscum contagiosum. British Journal of Dermatology, 2002; 146(4): 609-614.

9. Clebak K.T. \& Malone M.A. Skin Infections. Primary Care: Clinics in Office Practice, 2018; 45(3): 433-454 .doi:10.1016/j.pop.2018.05.004.

10. Kezic S. Skin barrier in atopic dermatitis. Frontiers in Bioscience, 2014; 19(3): 542. doi:10.2741/4225

11. Matejuk A. Skin Immunity. Archivum Immuno-logiae et Therapiae Experimentalis, 2017; 66(1): 45-54. doi:10.1007/s00005-017-0477-3.

12. Richmond J.M. \& Harris J.E. Immunology and Skin in Health and Disease. Cold Spring Harbor Perspectives in Medicine, 2014; 4(12): a015339-a015339 .doi : 10.1101/cshperspect.a015339.

13. Chen X., Anstey A.V. \& Bugert J.J. Molluscum contagiosum virus infection. The Lancet Infectious Diseases, 2013; 13(10): 877-888.doi:10.1016/s14733099(13)70109-9.

14. Hou J., Gu Y., Hou W., Wu S., Lou Y., Yang W., Zhu L., Hu Y., Sun M. and Xue H. P53 codon 72 polymorphism, human papillomavirus infection, and their interaction to oral carcinoma susceptibility. BMC Genetics, 2015; 16(1): doi:10.1186/s12863-015-0235-7.

15. Porter C.D. \& Archard L.C. Characterization and Physical Mapping of Molluscum Contagiosum Virus DNA and Location of a Sequence Capable of Encoding a Conserved Domain of Epidermal Growth Factor. Journal of General Virology, 1987; 68(3): 673-682. doi:10.1099/0022-1317-68-3-673.

16. Butel J.S. Viral carcinogenesis: revelation of molecular mechanisms and etiology of human disease. Carcinogenesis, 2000; 21(3): 405-426. doi:10.1093/ carcin/21.3.405. 
17. Mollamehmetoglu B., Erdem H. and Keles M. The Relationship between p53 Expression and Human Papillomavirus in Premalignant and Malignant Uterine Cervical Lesions. Open Journal of Pathology, 2016; 6: 73-78. doi: 10.4236/oj pathology.2016.62009.

18. Storey A., Thomas M., Kalita A., Harwood C., Gardiol D., Mantovani F., Breuer J., Leigh I.M., Matlashewski G. \& Banks L. Role of a p53 polymorphism in the development of human papilloma-virus-associated cancer. Nature, 1998; 393: 229-234.
19. Realacci M., Perrone G.A., Sale P., Tafani M., Di Vito M., Perrone-Donnorso R., ZOTTI G. \& Russo M.A. Detection of oncogenic HPV and identification of 72Arg polymorphic $\mathrm{p} 53$ by in situ PCR for clinical routine purposes. Anticancer Research, 2006; 26(4B): 30953103.

20. O'connor D.P., Kay E.W., Leader M., Atkins G.J., Murphy G.M. \& Mabruk M.J.E.M.F. p53 codon 72 polymorphism and human papillomavirus associated skin cancer. Journal of clinical pathology, 2001; 54(7): 539-542. 